\title{
POST-EDITING PROPORTION OF GOOGLE TRANSLATE IN INFORMATIVE AND EXPRESSIVE TEXTS
}

\author{
Aliurridha \\ ridhokdi@gmail.com \\ Sufriati Tanjung \\ sufriati@uny.ac.id \\ Universitas Negeri Yogyakarta
}

\begin{abstract}
The massive development of Google Translate (GT) is remarkable and there are many people all over the world use it. Yet, the texts that have been translated by GT still need post-editing by the human translator. This research aims to find the proportion that translator needed in post-editing when using GT in translating of informative and expressive text from English to Indonesia and what they need to pay attention in translating informative and expressive text using GT. The data in this research were words, phrases, and sentences that were analyzed using descriptive-comparative with error analysis at three different levels: accuracy and acceptability. The result shows that the proportion of post-editing for informative text is $5 \%$ for accuracy and $22 \%$ for acceptability, while in the expressive text, $33 \%$ for accuracy and $47 \%$ for acceptability. Humans need more effort in post-editing the expressive text because the structure of the sentences in the expressive text is more complex and longer. Furthermore, there are many CSI (Cultural Specific Items) found in the expressive text that makes the result unacceptable for TT readers. Another problem in using GT that the result of GT translation is literal while the expressive text has many of figurative meaning. It means that GT is acceptable for semantic translation. Thus, this research suggests GT can be used directly in translating informative text because informative, as long as the users conduct post-editing and the users should not use GT in translating expressive text directly except for decoding the semantic, pragmatic, and contextual meaning to find the suitable translation.
\end{abstract}

Keywords: Google translate; translation evaluation; informative text; expressive text

\section{INTRODUCTION}

The rapid development of information and communication technology makes information become a need for some people. Everyone from all over the world is free to exchange information without any restrictions. However, there are many languages all over the world and not all people can master other languages, it is absolutely necessary for people to have tools that can help them understand different languages. This development gave birth to what is called a machine translation. There are two kinds of machine translation, paid machine translation and free machine translation such as Babelfish, Google Translate and
Transtext. Google Translate (GT) is the most popular translation machine for people all over the world because GT has shown the best accuracy among other machines (Putri \& Ardi 2015, 183). Even though GT has shown the best accuracy, it still has so many errors in three different levels, namely morphology, syntax, and semantic (Halimah 2018). Yet, most of the beginner translators who work using internet resources did were more dependent on technology and they were not bothering to conduct post-editing (Şahin \& Dungan 2014). Furthermore, there are many students English as Foreigner Language relies on GT to perform their college assignments 
(Jaganathan, Hamzah \& Subramaniam 2014). Since, GT is the easiest and the most accessible SMT (Medvedev 2016), it makes GT becomes the most often used which made GT often gets output from the translation community so that the results of the translation are more advanced so that an evaluation of the results of the translation is needed from time to time. Thus, it is necessary to conduct a study about how much translatorsneed in conducting postediting when using GT to make it useful for its users. Furthermore, it can be useful for understanding what are the linguistic features that are difficult to translate using GT.

Ten years ago, GT was very bad, but as time went on, GT continued to grow better. Now, the quality of its translation has evolved to an extent that is understandable but it still needs to be used carefully by its users. Because GT does not provide grammar rule but based on algorithms on statistical analysis GT does not understand the meaning of words but translating them by the pattern of hundred millions of document for the best result (Putri \& Ardi 2015, 183). A translation is not only a word-by-word substitution process but it needs linguistic knowledge such as grammar, syntax, semantics, pragmatic and cultural understanding is needed, both in source languages (SL) and target languages (TL). The machine such as GT has no feeling and some cultural specific items carry emotional connotations that even for people of different languages are difficult to understand would be difficult for machines to translate. For example, the expression 'feel blue' cannot be understood by Arabic speakers because the 'blue' color is never associated with sadness or depression as in American culture (Ali \& Al-Rushaidi 2016, 193). Furthermore, GT cannot understand the contextual meaning which is beyond the meaning which caused translation errors. The knowledge of certain cultural specific items and contextual meaning are not available in GT.

GT is not only able to translate words, phrases, and sentences, but also translates pages, books, and even entire websites. However, GT does not care about the type of text and only translates it automatically. This type of text is important in translation because different texts have different functions. Various types of text, according to Reiss (Munday 2016), require a different translation strategy in translating them. Various strategies are used to achieve the equality of text functions in SL and TL. Thus, it is necessary to know the types of text that are translated. Reiss (in Munday 2016, 114) identified three types of text which were taken from language functions based on Buhler's function of language namely: representational functions, conative functions, and expressive functions. What is meant by representational function by Reiss is text that is classified as informative text where the text has a function to describe or report objects or objects and circumstances.Informative texts are those whose purpose is to inform by argumentation or description This informative text contains information, knowledge, and opinions(Henrique et al. 2017). The language dimension is logical and referential where the content and topics are useful for communication. In the informative texts, the focus of the text is on the content of a text because the goal of this text is to transmit information contained in it. Which includes the type of information text is the report text, news, procedural text or instructional text, research results, etc.

The second type of text is text that has conative functions defines as operative text where it has persuasive functions that directly involve the listener or reader. The language dimension used is dialogic. An operative text must have linguistic and psychological functions. This is because 
the operative text has the purpose of persuasion or inviting readers to agree with the speaker such as in political campaigns and advertisements. The last text is expressive text which has a function to convey the inner state or feelings of the author or speaker. The dimensions of expressive language are aesthetics where the writer creates expressions or thoughts creatively and artistically. In the expressive text, the focus of the text is on the form where the aim of this text is to transmit the aesthetic form of a text. Expressive texts usually appear in literary works such as poetry, drama texts, novels etc.

In order to find the proportion that translators needed in post-editing in translating the informative and expressive text, it is necessary to evaluate GT in translating the informative and expressive text. This research aims to evaluate the result of GT in translating informative and expressive texts from English to Indonesian to find the proportion that translators need in post-editing and to find the linguistic features that are difficult to translate using GT in the informative and expressive text. This research will be useful in providing understanding to GT users in helping to translate informative and expressive texts. Furthermore, this research is also useful to find what kind of linguistic features in the informative text and the expressive text that are difficult to translate by GT.

GT belongs to the category of automatic translation machines that use the Statistical Machine Translation (SMT) system. SMT provides good quality when there are many and highquality corpora. That is why the GT has evolved over time because GT can detect patterns in documents that have been translated by its users (Vidhayasai, Keyuravong \& Bunsom 2015, 140). By detecting patterns in the text that have been translated, GT can make intelligent guesses as to what the appropriate translation should be.
However, regardless of its progress, it is impossible to say that GT has succeeded in replacing the results of the human translator. The results of its translations are usually inefficient and still need to be edited by human translators. Huang explained the quality of the translation produced by SMT is still far below the quality of human translation and despite two decades of research and development supported by high-speed computers, the SMT that is now available to many internet users today is still very inaccurate (Huang 2011).

There were many studies conducted to find the errors of GT in translation. Putri\&Ardi (2015) who conducted research on GT in translating Indonesian folklores into English found that GT had missing-words, word-order, incorrect-word, and unknown-word errors. Ismail \& Hartono (2016) found that there were grammatical, terminology, omission, syntax, mistranslation, literalness, usage, punctuation, addition, ambiguity, wordform, capitalization, and spelling in Indonesian-English translation of news items. Furthermore, Napitupulu found that there were lexicosemantic, tense, preposition, word-order, distributionand-verb-group, as well as active-andpassive-voice errors in the ten abstracts undergraduate students' paper that were translated by GT (Napitupulu, 2017). Halimah (2018) who evaluated the result of English-Indonesia translation by GT for translating procedural text, found that there are morphology, syntax, and semantic errors.

Holmes (in Munday 2016) describes the assessment of translation as an applied translation study that includes revisions, evaluations, and reviews. The revision focuses on analyzing errors by comparing between SL and TL with the aim of improving the result of translation. The evaluation assesses the translation work for the training of translator students whereas the review 
is an assessment of the translation that has been published. In this study evaluation is the closest meaning to where the GT translation results are evaluated to see how well the translation results and see the amount of effort needed to edit the translation results. Furthermore, it can be used to find the linguistic features that are often errors in the result of GT.

In evaluating the quality of the translation, it is usually seen from its linguistic criteria, such as phonology, morphology, semantics, syntax, pragmatics, and discourse. There are at least three things that need to be considered, which are accuracy, acceptability, and readability of the translation results (Larson 1984).Most of machine translation assesment only focus on aspect of accuracy in microtextual level (Koponen 2010, 1). This research analyzed errors in microtextual and macro-textual level. Thus, this research evaluates accuracy and acceptability. The translation is considered accurate if the message delivered is in accordance with the meaning on the ST where there is no error in the transfer of meaning. In this research, the accuracy of translation can be achieved by no errors in words level such incorrect words, unknown words, addition words, and missing words. Incorrect words refer to the incorrect translation which can be seen by the lexicosemantic errors (Napitupulu 2017). Unknown words refer to the condition when GT cannot find the correct translation due to their lack of corpora and refers to the condition when GT cannot recognize the complex words (Ismail \& Hartono 2016). The missing words refer to the missing of an item that should be present in the sentences. It can be seen by the missing of important words that are used to express the meaning of a sentence and by the missing of words or letters that are used to make a grammatically correct sentence. The additional words refer to the additional words that make the sentence becomes ambiguous by their present.

The result of translations could be accurate, yet they could be unacceptable for the readers of TT because there are concepts that were different between ST and TT due to different cultures, experience in physical things, and different structures. Thus, translation is considered acceptable if the result of translation is acceptable with the TT readers. The acceptability requires no error in the terminology, cultural specific items, word orders, grammatical cohesion, and lexical cohesion. Terminology errors refer to the terminology words that are unacceptable in other languages and cultures. Cultural specific items (CSI) are words or phrases that are so bound and exclusive to one culture that makes it very difficult to translate into other cultural terms verbally (Robinson 2001, 171). CSI refers to idioms, metaphors, and proper names.Idioms are considered as CSI because idiomatic expressions somehow carry emotional connotations which the speakers in different languages are difficult to understand (Ali \& Al-Rushaidi 2016, 193). Metaphors are considered as CSI because metaphors are derived from humans' experiences in everyday life which reflect how they think, speak, and act (Lakoff \& Johnson 2003, 3). Thus, metaphor can be different between languages as much as it can be different between individuals. Proper names are considered as CSI because proper names related to geography, history, society, and cultures which are different between languages.

The word orders, grammatical cohesion, and lexical cohesion errors were analyzed in the unit of sentences. Word orders errors refer to the wrong structure of sentences which is formed by words. Furthermore, there is no error grammatical and lexical cohesion. Halliday \& Hasan (1976, 5-6) theory which grammatical cohesion consisting of four types, namely: reference, 
substitution, ellipsis, and conjunction. While lexical cohesion includes reiteration and collocation. Reiteration covers synonyms, antonyms, repetitions, hyponyms. For example in the text 'They stimulated them to be aware of their situation' translates to Mereka mendorong mereka untuk menyadari situasi mereka. The use of reference mereka creates an error in grammatical cohesion which makes it very confusing for the TT reader. The reference mereka should be changed one of them or even both of them to meet the level of readability by looking at the references. Another example is the word 'God' that is translated into Allah but in the next sentence, it was translated into Tuhan. It creates an error in the repetition which means there is no coherence of the repetition of the translation results.

\section{RESEARCH METHOD}

This research is a descriptive comparative study using error analysis. The data in this research were words and phrases. The data was taken from theconversation.com as a source of informative texts and the English version of Umberto Eco's novel The Name of Rose as a source of expressive text. The data of informative text was taken from an article that was published by theconversation.com whose title was Indonesian Physician Spur Nationalist Movements during the Dutch Colonial Rule. The data of expressive text was taken from the prologue of the novel The Name of Rose. The data were analyzed using a model of error analysis which analyzed the errors at accuracy and acceptability levels. The errors in the accuracy and acceptability level were counted by the total unit of translations per total errors in every level. In the accuracy level, the unit of translations occurred in words level while in the acceptability the unit of translation could be in words, phrases, and sentence. The errors in every level were counted by this formula: $\mathrm{n} / \sum 100 \%$ where $\mathrm{n}$ : the total errors

$\sum$ : total unit of translations (could be words, phrase, or sentences, depend on what are the units of translation)

The procedure of this study includes: (1) translating informative and expressive texts directly using GT; (2) measuring the errors in the result of GT translation in the accuracy and acceptability level; (3) describing the results; and (4) drawing conclusions.

\section{RESULTS AND DISCUSSION}

The results of data analysis showed that the errors in the informative text are $5 \%$ in the accuracy level (Table 1) and $22 \%$ in the acceptability level (Table 2). In the informative text, terminology words are the most difficult and the most problematic linguistic features when translated using GT.

Table 1: The Accuracy of Informative Text Translation

\begin{tabular}{lc}
\hline \multicolumn{1}{c}{ Kinds of Errors } & $\begin{array}{c}\text { Number of } \\
\text { Errors }\end{array}$ \\
\hline Lexicosemantic & 29 \\
Unknown word & 9 \\
Additions word & 1 \\
Missing word & 5 \\
Total Errors & $\mathbf{4 4}$ \\
Translation units & $\mathbf{9 2 9}$ \\
Error Percentage & $\mathbf{5 \%}$ \\
\hline
\end{tabular}

Table 2: The Acceptability of Informative Text Translation

\begin{tabular}{lcc}
\hline \multicolumn{1}{c}{ Kinds of Error } & $\begin{array}{c}\text { Trans. } \\
\text { Units }\end{array}$ & $\begin{array}{c}\text { Num. of } \\
\text { Errors }\end{array}$ \\
\hline Terminology & 26 & 14 \\
Metaphor & 1 & 0 \\
Idiom & 0 & 0 \\
Proper name & 9 & 0 \\
Total & $\mathbf{3 6}$ & $\mathbf{1 4}$ \\
Error percentage & & $\mathbf{3 3 \%}$ \\
Word order & & 3 \\
Grammatical cohesion & & 5 \\
Lexical cohesion & & 0 \\
Total & $\mathbf{6 3}$ & $\mathbf{8}$ \\
Error percentage & & $\mathbf{1 2 \%}$ \\
Average Error percentage & $\mathbf{2 2 \%}$ \\
\hline
\end{tabular}

For expressive text, results of data analysis showed that the errors in the expressive text were $28 \%$ in the 
accuracy level (Table 3) and $47 \%$ in the acceptability level (Table 4). In the expressive text, metaphorical expressions are the most difficult and the most problematic linguistic features when translated using GT.

Table 3: The Accuracy of Expressive Text Translation

\begin{tabular}{lc}
\hline Kinds of Errors & $\begin{array}{c}\text { Number of } \\
\text { Errors }\end{array}$ \\
\hline Lexicosemantic & 223 \\
Unknown word & 7 \\
Additions word & 4 \\
Missing word & 11 \\
Total Errors & $\mathbf{2 6 1}$ \\
Translation units & $\mathbf{9 3 0}$ \\
Error Percentage & $\mathbf{2 8 \%}$ \\
\hline
\end{tabular}

Table 4: The Acceptability of Expressive Text Translation

\begin{tabular}{lcc}
\hline \multicolumn{1}{c}{ Kinds of Error } & $\begin{array}{c}\text { Trans. } \\
\text { Unit }\end{array}$ & $\begin{array}{c}\text { Num. of } \\
\text { Errors }\end{array}$ \\
\hline Terminology & 26 & 9 \\
Metaphor & 19 & 12 \\
Idiom & 17 & 3 \\
Proper name & 16 & 7 \\
Total & $\mathbf{7 8}$ & $\mathbf{3 1}$ \\
Error percentage & & $\mathbf{3 9 \%}$ \\
Word order & & 7 \\
Grammatical cohesion & & 5 \\
Lexical cohesion & & 4 \\
Total & $\mathbf{2 9}$ & $\mathbf{1 6}$ \\
Error percentage & & $\mathbf{5 5 \%}$ \\
Average error percentage & $\mathbf{4 7 \%}$ \\
\hline
\end{tabular}

\section{Informative Text Translation}

The result shows that the informative text is better to translate using GT at every level, whether accuracy or acceptability level. The result shows that the informative text was almost accurate when it is translated using GT. It means human translators only need a little proportion for post-editing. These following samples are the errors found in the accuracy level. In the accuracy level, there is a sample lexicosemantic error which can be seen in Datum 1.

\section{Datum 1}

ST : They have characterized colonial medicine as a tool of empire.

TT : Mereka telah mencirikan pengobatan kolonial sebagai alat kekaisaran.

In Datum 1, the word 'characterized' is translated into mencirikan which has distorted the meaning in TL by the lexicosemantic error. The word 'characterized' should be translated as menggolongkan so that there is no lexicosemantic error that makes the translation inaccurate. This error happens because GT belongs to SMT which most of the result translation of 'characterized' in GT is mencirikan.Another error in the accuracy level is unknown word errorwhich can be seen in Datum 2.

\section{Datum 2}

ST: When Indonesian physicians took up positions within the colonial health service, they quickly realised that the medical degrees from the colonial medical colleges in Batavia and Surabaya (the NIAS) were considered inferior to those granted by medical schools affiliated with European universities.

TT : Ketika dokter Indonesia mengambil posisi dalam pelayanan kesehatan kolonial, mereka dengan cepat menyadari bahwa gelar medis dari kolese kedokteran kolonial di Batavia dan Surabaya (NIAS) dianggap lebih rendah daripada yang diberikan oleh sekolahsekolah medial yang berafiliasi dengan universitas-universitas Eropa.

There are two unknown words in the result of translation, namely kolese and medial that can be seen in Datum 2. Kolese actually has meanings in Indonesian dictionary Kamus Besar Bahasa Indonesia (KBBI) which means 'council', 'school', or 'academy'. Yet, it is very rare to be used. It would be better if it was translated into perguruan 
tinggi which is most often and more familiar to be used in TT. Furthermore, medial has no meaning at all in KBBI. It should be translated into medis which will be accurate in TT. The result shows that the users GT does not need to worry about the unknown word errors because it only occurs twice from 929 of translation units. This resultis in line withPutri \& Ardi's (2015, 186) research, who found that unknown word errors have the least proportion.

Additional words errors are also found in the informative text which can be seen in Datum 3.

\section{Datum 3}

ST : ... and transmission of disease held the promise that illness could be cured, lives saved and suffering alleviated.

TT : ... dan penularan penyakit memegang janji bahwa penyakit dapat disembuhkan, kehidupan yang diselamatkan dan penderitaan diringankan.

The phrase 'live saved' was translated into kehidupan yang diselamatkan.. The occurrence of the word yang in TT made the result of translation was less accurate. The word yang should not occur in TT to make the text more accurate. Furthermore, there are missing word errors found in the informative text that can be seen in Datum 4.

Datum 4

ST : Despite their training and medical skills, they faced discrimination in their professional work compared to their European-educated colleagues.

TT: Meskipun pelatihan dan keterampilan medis mereka, mereka menghadapi diskriminasi dalam pekerjaan profesional mereka dibandingkan dengan rekan-rekan mereka yang berpendidikan Eropa.

In Datum 4 there is a missing word between the word meskipun and pelatihan which makes the text is less accurate. It needs a conjunction dengan between those two words to make it more accurate.

In the acceptability level of the informative text, there are many terminology errors. There are 14 terminology errors from a total of 26 units of translation. It means that more than half or total terminology words were failed to translate using GT. Furthermore, there are no errors in metaphorical expression, idiomatic expression, and proper names, found in this research. Yet, there are some errors in the unit of sentences which are words order errors and grammatical cohesion errors. The sample of terminology error can be seen in Datum 5 .

\section{Datum 5}

ST : Historians of medicine investigate discoveries within medicine and their effects on everyday life, the organisation of medical care and the medical profession.

TT : Sejarawan obat menyelidiki penemuan dalam pengobatan dan pengaruhnya pada kehidupan sehari-hari, organisasi perawatan medis dan profesi medis.

The terminology words 'historians of medicine was translated into sejarawan obat which was unacceptable in TT. The word 'medicine' if it appears alone as a word it would be obat. Then, if the unit of translation occurs in word level, it could be correct to translate 'medicine' into obat. Yet, in the Datum 5, the unit of translation is in phrase-level which should be translated into sejarawan medis atau sejarawan kedokteran. As Ismail \& Hartono $(2016,5)$ found that most of the terminology errors were caused by word-to-word translation for the translation in the unit of phrase.

There are no metaphors, idioms, and proper names errors in this text because the informative text has only 1 metaphorical expression, there is no idiomatic expression, and there are 9 
proper names which are more familiar and more frequently occur in the corpora of GT. It happens because the language dimension in the informative text is logical and referential. Furthermore, the names of person or place that found in this text really existed which make them more familiar and frequently used. The only metaphorical expression found in this text was in the title of the text. It can be seen in Datum 6.

\section{Datum 6}

ST : Indonesian physicians spurred nationalist movements during Dutch colonial rule.

$\begin{array}{rlr}\mathrm{TT}: & \text { Dokter Indonesia } & \text { memacu } \\ & \text { gerakan nasionalis selama } \\ & \text { pemerintahan kolonial Belanda. }\end{array}$

In Datum 6 the word 'spurred' was translated into memacu which has a metaphorical meaning. The word memacu in Indonesia language is a verb which literally means to make it run fast. The word memacu is usually used for a rider who rides a horse or motorbike. The word memacu when it combines to nationalist movements, it creates a metaphorical meaning because it has afigural displacementthat causes semantic tension (Halley 1980, 143). Yet, the result of translation was accurate and acceptable. Furthermore, both of them carry the same emotional connotations.

In the unit of sentences, there are word order errors also found in the informative text (Datum 7) along with the grammatical cohesion (Datum 8). Yet, there is no error in lexical cohesion.

\section{Datum 7}

ST : The founders of Budi Utomo were convinced modern science, technology and medicine could transform the lives of all Javanese.

TT : Para pendiri Budi Utomo yakin ilmu pengetahuan modern, teknologi dan obat-obatan dapat mengubah kehidupan semua orang Jawa.

In Datum 7 the 'modern science, technology, and medicine' was accurately translated into ilmu pengetahuan modern, teknologi dan obat-obatan. Yet it was unacceptable because the word modern'should occur after obat-obatan in TT to make the translation acceptable. The occurence of modern after ilmu pengetahuan make the modern as modifier only for ilmu pengetahuan and not for teknologi and obat-obatan whereas in ST modern was the modifier for the 'science, technology, and medicine' altogether.

\section{Datum 8}

ST : They stimulated them to examine the conditions in the colonies.

TT: Mereka mendorong mereka untuk memeriksa kondisi di koloni.

The result of translation was accurate but it is unacceptable and difficult to read in for TT readers. The use of reference mereka was very confusing for the TT readers and it should be changed one of them or even both of them to meet the level of acceptability by looking at the referential meaning of they or them.

\section{Expressive Text Translation}

The expressive text has a bigger proportion of human translators in conducting post-editing. It can be seen by the result of translation using GT at every level, whether in accuracy or acceptabilitylevel.The proportion of errors, in acceptability level, shows metaphorical expressions become the most difficult to translate using GT for the expressive text. Even though metaphors and idioms carry emotional connotation and both of them have the category of figurative expression, yet metaphors are difficult to translate because the form of metaphor is not fixed as idioms (Newmark 1988, 104). Furthermore, metaphor can be difficult to translate because metaphors can be a 
specific expression that is used of a person based on his experience as an individual or part of society (Lakoff \& Johnson 2003; Nirmala 2011, 264).The proper names are also difficult to translate in the expressive text because this text is a fiction that is not based on the original actual event and the names can be based on the imagination of the author. The other problem is in the expressive text sentences are longer and more complex which cause more errors in the unit of sentences such as word orders, grammatical cohesion, and lexical cohesion. In the expressive text, there are clauses in every sentence and most of the sentences have more than three clauses. It can be seen in Datum 9 which a sentence has more than three clauses which cause errors in the accuracy and acceptability level.

\section{Datum 9}

ST : Having reached the end of my poor sinner's life, my hair now white, I grow oldas the world does, waiting to be lost in the bottomless pit of silentand deserted divinity, sharing in the light of angelic intelligences; confined now with my heavy, ailing body in this cell in the dear monastery of Melk, I prepare to leave onthis parchment my testimony as to the wondrous and terrible events that I happened to observe in my youth, now repeating verbatim all I saw andheard, without venturing to seek a design, as if to leave to those who will come after (if the Antichrist has not come first) signs of signs, so that the prayer of deciphering may be exercised on them.

TT: Setelah mencapai akhir dari kehidupan orang berdosa yang miskin, rambut saya sekarang putih, saya menjadi tuaseperti dunia, menunggu untuk hilang dalam jurang kesunyian yang kosong dan sepi, berbagi dalam cahaya kecerdasan malaikat; sekarang dengan tubuhku yang berat dan sakit di sel inidi biara Melkyang tersayang, aku bersiap untuk meninggalkanperkamen ini kesaksianku mengenai kejadian menakjubkan dan mengerikan yang aku saksikan di masa mudaku, sekarang mengulang kata demi kata yang kulihat dan mendengar, tanpa berusaha mencari desain, seolah-olah meninggalkan mereka yang akan datang sesudahnya (jika Antikristus belum datang) tandatanda tanda, sehingga doa penguraian dapat dilakukan pada mereka.

In Datum 9, there is a distortion of meaning which cause lexicosemantic error in the translation of 'poor' into miskin and 'deciphering' into penguraian. The poor is literally means miskin in TT. Yet, in this context, it means malang because it serves the same function with the ST which to express the feeling of helpless of the speaker. The same thing happens for 'deciphering' into penguraian which is correct if it is stand alone and apart from the context. By looking at the context the 'deciphering' should be translated into memberi makna. Another error in Datum 9 is missing word error that can be seen in the phrase 'deserted divinity' which was not translated but omitted.

The Datum 9 also contains errors which occurred in acceptability level such us metaphor errors, idiom errors, words order errors, grammatical, and lexical cohesion errors.The metaphorical expression 'I grow old as the world does' which was translated into saya menjadi tua seperti dunia unacceptable for TT reader and should be translated into saya menjadi tua seperti bumi yang semakin tua. Furthermore, the metaphorical expression 'waiting to be lost in the bottomless pit of silent' was unacceptable for TT readers because 
menunggu untuk hilang dalam jurang kesunyian yang kosong dan sepi should be translated into menunggu untuk hilang dalam lubang kesunyian tanpa dasar. Both of them cause errors in acceptability because they are pragmatically failed to convey the meaning of ST. They both failed in convey the aesthetic function of the ST in TT. The error in idiomatic expression can be seen in the phrase 'sign of sign' and 'come after' which were translated into tanda tanda tanda and datang setelah. The idiomatic expression 'sign of sign' should be translated into tanda demi tanda and the idiomatic expression 'come after' should be translated into akan mencari which make them more acceptable for TT readers. The result of GT translation tends to be literal which failed to convey the figurative meaning of the expressions.

In the unit of sentences, there is a word order error in the translation of ' $I$ prepare to leave on this parchment my testimony' into aku bersiap untuk meninggalkan perkamen ini kesaksianku. The word kesaksianku should be occurred after meninggalkan to make the correct word order and make it acceptable and more understandable for the TT readers. The grammatical cohesion error which can be seen by there is no conjunction karena which should be occurred in the first paragraph to make the text is more readable for TT readers. Furthermore, the clause 'sharing in the light of angelic intelligences' which was translated into berbagi dalam cahaya kecerdasan malaikat should have a conjunction sementara before the clause to make it more readable. There is an error of lexical cohesion which can be seen by the collocation 'I saw and heard' which was translated into kulihat dan mendengar. The result of translation causes an error in collocation between the words before the conjunction dan where before conjunction possessive pronoun $k u$ but after the conjunction there is no pronoun $k u$.

These findings show that there are significant differences in translating informative texts and expressive texts using GT, especially in accuracy level. The results of the analysis show that the expressive text is more difficult to translate because the sentences are more complex and longer which causes the translation results to be lacking in various levels. The corpora of GT is also to be lacking in translating expressive text because the expressive text is very concerned with expressive functions, whose function is to convey the inner state or feelings of the author or speaker with an aesthetic dimension that is a construction of author creativity which is often different in other languages. The result of GT translation failed in expressive text because GT translated literally, while there were many CSI which contains figurative meaning in the expressive text. These CSI's often do not have the same form, function, and carry different connotations in different languages.

\section{CONCLUSION}

The proportion of post-editing in translating expressive text using GT is bigger than informative text. Thus, the users need more effort in conducting post-editing using GT. In the informative text, the proportion of human intervention in conducting postediting in translating English to Indonesian was5\% in the accuracy level and $22 \%$ in the acceptability level. In the expressive texts, the proportion of post-editing intranslating English to Indonesian using GT $28 \%$ in the accuracy level and $47 \%$ in the acceptability level. This research suggests GT can be used directly in translating informative text, as long as the user taking time to conduct postediting. In the informative texts, people should be careful in terminology words.

This study also suggests that people should not use GT in translating 
expressive texts directly and must pay attention to cultural specific items, especially metaphorical expressions because more than 50\% metaphorical expressions in this research were errors. Another problem in using GT to translate the expressive text is the result of translation was awkward because because the result of GT translation is literal which cause GT annot convey pragmatic and contextual meaning. Furthermore, GT also cannot translate the style of the author. The result of GT is too formal for expressive text and more suitable for informative text. It can be seen by the use ofpronoun saya instead of aku which is unnatural in fiction because saya is too formal for a literature work. Thus for the expressive text, GT should be used to decode the semantic, pragmatic, and contextual meaning to help human translator in choose the appropriate translations.

\section{REFERENCES}

Ali, HIH, \& SMS Al-Rushaidi, 2016. "Translating Idiomatic Expressions from English into Arabic: Difficulties and Strategies". Arab World English Journal (AWEJ), 7(4):187-201.

Halimah. 2018. Error Analysis in EnglishIndonesian Machine Translation. In Proceeding of 1st International Seminar on Innovation and Development of Education of Asia. July 14th, 2018: 2936

Halley, MC. 1980. "Concrete Abstraction: The Linguistic Universe of Metaphors". In MKL. Ching, MC. Halley \& FR. Lonsford (Eds.). Linguistic Perspective on Literature. London: Routledge \& Kegan Paul Ltd.

Halliday, MAK, \& R. Hasan. 1976. Cohesion in English. New York: Longman.

Henrique, Arruda D, LF. Costa \& DR. Ammancio, 2017. "Using Complex Networks for Text Classification: Discrimanting Informative and Imaginative Documents". Journal of English Language Teaching, 12 (2): 2

Huang, HJ. 2011. "Intermediality and Human vs Machine Translation".
Comparative Literature and Culture, 13 (3): 1-11. Retrieved at <https://doi. org/htps://doi.org/10.7771/1481-4374. 1796>

Ismail, A \& R.Hartono. 2016. "Errors Made in Google Translate In the Indonesian to English Translation of Newes Item Texts". Journal of English Language Teaching, 5 (2): 1-6

Jaganathan, P, M. Hamzah \& I. Subramaniam, (2014). "An Analysis of Google Translate Use in Decoding Contextual Semanticity among EFL Learners". Asian Journal of Research in Social Sciences and Humanities, 4 (9): 1-13. Retrieved at <https://doi.org/ 10.5958/2249-7315.2014.00962.9>

Koponen, M. 2010. "Assessing Machine Translation Quality with Error Analysis". In Electronic Proceedings of the KäTu Symposium on Translation and Interpreting Studies Translation and Interpreting Studies, 4: 1-12

Lakoff, G, \& M. Johnson. 2003. Metaphors We Live By. Chicago: University of Chicago Press.

Larson, ML. 1984. Meaning BasedTranslation. Boston: University Press of America

Medvedev, G. 2016. Google Translate in Teaching English. Journal of Teaching English for Specific and Academic Purposes, 4 (1): 181-193

Munday, J. 2016. Introducing Translation Studies: Theories and Applications (4th ed.). New York: Routledge.

Napitupulu, S. 2017. "Analyzing Indonesian-English Abstract Translation in View of Translation Errors by Google Translate". International Journal of English Language and Linguistics Research, 5 (2): $15-23$

Newmark, P. 1988. A Textbook of Translation. Englewood Cliffs: PrenticeHall International.

Nirmala, D. 2011. Metaphors: Universal, Specific, and Public. Bahasa dan Seni, 39 (2): 250-265.

Putri, GD \& Ardi, H. 2015. "Types of Errors Found in Google Translation: A Model of MT Evaluation". In Proceeding Third International Seminar on English Language and Teaching (ISELT-3): 183188). 
Robinson, D. 2001. Becoming A Translator: An Accelerated Course. London: Routledge

Sahin, M \& Dungan, N. 2014. "Translation Testing and Evaluation: A Study on Methods and Needs". The International Journal for Translation \& Interpreting Research, 6 (2): 67-90. Retrieved at https://doi.org/ti.106202.

2014.a05/Abstract

Vidhayasai, T, S.Keyuravong \& T. Bunsom, 2015. "Investigating the Use of Google Translate in Terms and Conditions" in an Airline's Official Website: Errors and Implications". PASAA, 49: 137-169 